\title{
Ruination and the Production of Space in Contemporary China
}

Judith Audin

\section{(2) OpenEdition}

\section{Journals}

Electronic version

URL: https://journals.openedition.org/chinaperspectives/12855

DOI: 10.4000/chinaperspectives. 12855

ISSN: 1996-4617

\section{Publisher}

Centre d'étude français sur la Chine contemporaine

Printed version

Date of publication: 1 December 2021

Number of pages: 3-7

ISSN: 2070-3449

\section{Electronic reference}

Judith Audin, "Ruination and the Production of Space in Contemporary China", China Perspectives [Online], 2021/4 | 2021, Online since 01 December 2021, connection on 06 December 2022. URL: http://journals.openedition.org/chinaperspectives/12855; DOI: https://doi.org/10.4000/ chinaperspectives. 12855 


\title{
Ruination and the Production of Space in Contemporary China
}

\author{
JUDITH AUDIN
}

\section{Beyond the exceptional lens: Ruination and the shaping of ordinary spaces in China}

Urban ruins constitute ubiquitous spaces in contemporary China: from neighbourhoods and areas undergoing urban demolition to newly built "ghost cities" (guicheng 鬼城), from industrial wastelands to forgotten buildings and abandoned theme parks in various states of disrepair. The familiar strangeness of Chinese urban ruins and abandoned places has been seen and described through the lenses of filmmakers, photographers, and journalists. As in other contexts, rubble, ruins, and abandoned places fascinate, as architect Ignasi de Solà-Morales Rubió explains with his concept of the "terrain vague":

Empty, abandoned space in which a series of occurrences have taken place seems to subjugate the eye of the urban photographer. Such urban space, which I will denote by the French expression terrain vague, assumes the status of fascination, the most solvent sign with which to indicate what cities are and what our experience of them is. (2014: 25)

While these ruinscapes tend to be mediatised as exceptional and spectacular, analysed as "unreal" (Lam 2020b), "vanishing" (Messmer and Chuang 2013), or empty, this special feature argues that ruination deserves to be studied through the angle of the "production of space." As Henri Lefebvre (1991) explains, any given space is produced by social interactions, including spaces in ruins, where we would not expect to find people still using them in everyday life (see cover photo). Ruins, rubble, and abandoned places are here conceived as ordinary spaces produced by individuals, social groups, and any other actors that inhabit, practice, or represent such places. The four articles in this special feature contain original materials on ruins, abandoned places, and derelict buildings in various Chinese contexts such as China's most famous "ghost city," abandoned places in Beijing, derelict neighbourhoods in the urban fringes and in rural areas, and an abandoned coal town. From the angle of ordinary space production, the articles focus on the interactions between such spaces and the people that use them: remaining residents from different generations, journalists, and researchers, as well as tourists and urban explorers.

\section{Ruination and dereliction as social facts}

Ruination has generated a rich body of research on contemporary Chinese society, driven by the unprecedented trajectory of urbanisation since the reform era. Scholarly publications on ruins, rubble, and abandoned places exist in the fields of political history (Lee 2009; Li 2020), cultural history (Wu 2012), geography and architecture (Sorace and Hurst 2015; Woodworth and Wallace 2017), as well as political science (Sorace 2017; Xu 2017), and visual and ecocritical studies (Li 2009; Chu 2012; Lam 2013a; McGrath 2014; Ortells-Nicolau 2015; Schulz 2016). The rich body of research on urban demolition (Ren 2014) and displacement (Padovani 2005) has contributed to taking urban ruins and the interactions with local residents as full social facts. These perspectives on the Chinese built environment produced new concepts out of multidisciplinary approaches. More precisely, many published works in the social sciences focus on the rubble of urban destruction with qualitative research on the social impact of "demolition-relocation" (chaiqian 拆遷), and especially on violence, resistance, and resilience in neighbourhoods and "urban villages" (chengzhongcun 城中村) under demolition (Vale and Campanella 2005; Ho 2013; Shao 2013; Wu, Zhang, and Webster 2013).

Yet, beyond urban demolition and displacement, ruination is here conceived as a process happening in many overlooked social and spatial dimensions of Chinese society, from dilapidated buildings and depopulated villages to industrial wastelands and unfinished-abandoned buildings (lanweilou 爛尾樓) produced by real estate speculation, as well as abandoned Cold War cities, ruins of natural disasters, and many more. The difficulty lies in the scientific interpretation of such ruins, whose landscapes reveal a sharp contrast between the planned project - or "conceived space" according to Lefebvre (1991) - and the "perceived" reality on the ground. Some studies on contemporary ruins tend to exceptionalise these spaces, seen as urban pathologies (Shepard 2015; Sorace and Hurst 2015), or to study them through aesthetic approaches (Braester 2010; Ortells-Nicolau 2015; Nieszczrzeweska 2015; Valjakka and Wang 2018). Qualitative studies based on solid fieldwork have helped grasp how the textures and materialities of Chinese urban spaces in disrepair or abandoned continue to have strong social and political effects (Chu 2014; Ulfstjerne 2017). Grounded research also presents how ruins can produce new systems of "value" (following Davidov 2016), both economic and aesthetic, from street artists and urban explorers inspired by urban ruins and abandoned places (Massey forthcoming) to waste pickers making a living out of scrapping in such spaces (Wu and Zhang 2019). In this special feature, the study of ruination gives special attention to the temporalities of these spaces (Garrett 2011). Geographer Marc Augé explains that "ruins convey the feeling of time that passes and lasts" (2003: 92). For instance, by exploring abandoned cities from 
the Cold War era, Tong Lam produces original materials for the study of twentieth-century China (2020a). As Max Woodworth puts forward in his article on Ordos in Inner Mongolia, ruination opens up new perspectives, not only on urban demolition, but also on various cycles of the built environment, including the construction phase. He describes it as follows: "Ruin is always a looming possibility, not just at the end of a structure's life cycle, but throughout its existence, including during the construction phase." Ruination, as a multifaceted process, helps bring to light overlooked social processes in contemporary China, beyond the lenses of demolition, heritagisation, or full decline.

Urban ruins are part of what Anna Jorgensen calls "urban wildscapes": "Urban spaces where natural as opposed to human agency appears to be shaping the land, especially where there is spontaneous growth of vegetation through natural succession" (2012: 1). Rubble, ruins, and abandoned places in China contribute to various urban wildscapes reshaping human agency. Urban wilderness is a key element of the attraction of abandoned places and urban ruins for Chinese urban explorers, who visit these spaces as a way to alleviate "urban alienation and everyday boredom," as Annabella Massey argues in her article. Her study reveals new forms of human agency in the city, especially as "urbex narratives often draw links between urban exploration and the reclamation of a childlike sense of discovery, appealing to those who feel dissatisfied with ordinary city life." In another approach of "ludic" and "childlike" practices of ruins, rubble, and wastelands, Camille Salgues's article explores the ordinary social processes that characterise children's uses of their neighbourhoods in an urban village under demolition in Shanghai and in a depopulated village in Guangdong Province. The playful dimension of ruins becomes central through the experience of children, shedding new light on the social life of derelict neighbourhoods. This exploration, focusing on children, displays another form of "perceived space" than the common spatial practices of migrant workers in the same environment. By studying the overlooked practices of children in interaction with their neighbourhood, Camille Salgues shows that urban ruins constitute a full element of their mental maps in a dilapidated area of Shanghai's periphery and a left-behind village in the Chinese countryside: "The abandoned spaces, linked to the dispersion phenomena, provide isolated places, suitable for secrets, exploration, and activities (....)." Such spaces are essential spaces for childhood development, providing settings where children create their own itineraries, developing risk management as well as physical skills. Indeed, ruination induces new forms of agency through specific processes of socialisation. Judith Audin's article, based on fieldwork in Kouquan - an uninhabited coal town in Datong -, argues that ruination does not correspond to the destruction of social ties. It induces specific spatialities, routinised experiences of the abandoned buildings by old residents, but also new experiences of these spaces by former residents, journalists, filmmakers etc., that reconnect rather than disconnect people and places in this former industrial town. Because they understand ruination as a process contributing to the production of ordinary spaces, the articles in this special issue analyse more closely what Lefebvre calls the "perceived space" of ruination (1991), that is to say the various social processes at play, taking the local contexts into full consideration.

\section{Challenging images: Urban exploration and photography}

Visiting or studying contemporary ruins is intimately linked with the production of images. Approaching ruination in China as an ordinary research object beyond fascination or aesthetisation constitutes a challenging, ambiguous effort that engages not only local actors, but also researchers in a form of introspection. Urban exploration (chengshi tanxian 城市探險) - the visiting and documentation of derelict manmade structures and abandoned places - has developed in recent years and has inspired various research methods in social sciences (Garrett 2014a, 2014b; Offenstadt 2018). This approach has proven useful to infiltrate undocumented places and to access new fields of knowledge and offer a critical understanding of the Chinese city (Lam 2013b; Audin 2018). In recent years, the practice of urban exploration also developed as a creative practice in the Chinese urban space. In this issue's article, Annabella Massey studies the way these urban explorers produce and exchange images of ruins on specific forums. She analyses more precisely the photographic work of Zhao Yang 趙陽, the Cooling Plan project, understood by Massey as "present[ing] the ruin as a creative refuge that helps the explorer build a restorative sense of individual autonomy and mitigates the negative mental impact of the 'seen' city."

By exploring urban ruins in qualitative perspective, the articles in this special issue also produce original contributions on the methodological challenges of studying ruination and dereliction. One key aspect is the use of photography during fieldwork. An important methodological issue is the aesthetisation of the object, all the more so as urban exploration is often connected to the systematic use of photography. Between pure documentation of the context and aesthetic production, images produced through this medium should be analysed more closely. In his study of an urban village under demolition - Xian Village in Guangzhou - Tong Lam develops a "critical aesthetics of resistance through [his] own intervention and dialogue with the environment" (2021). The "ghost city" imagery studied in this special issue by Max Woodworth uses the photographic lens to highlight how the Chinese real estate industry has produced "spectacular instances of disuse." Woodworth critically reflects on his own status as a researcher while discussing the use of photography in Ordos: photos of this "ghost city" convey a "dramatically eerie impression of abandonment and ruin." The author indeed wonders how "fieldwork images of spaces commonly pictured as ruins confirm or disrupt the idea of ruins."

\section{Ruination and alternative geographies}

The empirical studies contained in this special feature are useful to understanding contemporary Chinese ruins grounded in specific contexts with a focus on the ways local communities interact with them. More precisely, the articles show how residents (Audin and Salgues), but also urban explorers (Audin and Massey), journalists, and researchers (Woodworth) interact with these ruins. Audin's and Salgues's articles are based on ethnographic approaches that participate in a critical understanding of Chinese urban development by highlighting dynamic economic, political, ecological, social, and cultural processes embedded in the ruins. In both articles, the authors follow closely the itineraries of overlooked communities in overlooked spaces: migrant workers' children in Shanghai's outskirts and in a village in Guangdong, as well as old residents in a coal town near Datong, continue to interact with disused buildings and abandoned spaces. Grounded acts of dwelling, games, and other forms of socialisation characterise these spaces. More broadly, such methodology allows an acute analysis of the ways in which specific social groups 
practice, use, think, and shape abandoned or derelict spaces. Far from being left empty, the material texture and social contexts of abandoned spaces stimulate sociocultural creativity and adaptation. Hence, considering the various forms and processes of ruination, the articles in this issue help consolidate not only knowledge on contemporary China but also geographic knowledge on ruination. They offer new perspectives on how local communities and other various actors invest the ruins and derelict buildings. In his article on migrant workers' children in Shanghai and Guangdong, using the concepts of concentration and dispersion, Camille Salgues concentrates his attention on how children use and represent their dilapidated neighbourhoods, producing alternative geographies of the everyday less focused on urban density. In his critical discussion on fieldwork photography in Kangbashi New District in Ordos, Max Woodworth confronts the "conceived" landscape of planners to his bottom-up spatial experience. Finally, Annabella Massey's paper discloses an alternative geography of Chinese mega-cities such as Beijing and Shanghai by envisioning the city through the ludic use of abandoned places by Chinese urban explorers.

\section{The lived space of ruination}

Exploring the processes of vanishing, as well as the presence (or absence) of traces (Ginzburg 1980) can bring to light how individuals and social groups consider these spaces and their trajectories. How does dereliction contribute to making places and communities? The articles manage to reveal the practices of individuals and social groups in these spaces even if they are "invisible" to others (Huang and Yi 2015). In his theory of the production of space, Lefebvre develops a third dimension, more cultural, called the "lived space": through a dynamic process, spaces become attributed with symbols, representations, and values (1991). How do inhabitants or other actors react when confronted with processes of ruination, depopulation, abandonment, or disrepair? Much of the research on the "lived space" of ruination has focused on traumatic ruins stemming from natural disasters, widely studied in the case of the 2008 Sichuan earthquake in China, which generate complex effects and affects, from the "politics of compassion" (Xu 2017) to difficult memory issues (Xu 2018). The landscape of destruction generated ambiguity in the double meaning of the notion of "ruin" in Chinese: ruins as rubble (feixu 廢噓), but also ruins as a historical site (yizhi 遺址), producing both extreme trauma among the local population as well as new forms of dark tourism through a heritagisation plan leading to the "commodification of both the living and the dead" (Le Mentec and Zhang 2017). This special issue contributes to this aspect by studying the lived space of ruination in ordinary spaces. In their analyses of dereliction and ruination, the articles fully consider the representations produced by social actions and reactions in such spaces. In his article on Ordos, Max Woodworth wonders if his "fieldwork photos of ambiguous ruin sites perform the same critical or ideological work as the formal ruin photograph genre." Camille Salgues's article follows the everyday itineraries of children, and he accurately describes how their daily wandering in the ruins creates feelings of freedom, joy, and fear. In her contribution, Annabella Massey highlights a "more amateur and everyday dimension of Chinese ruin representation" in the way urban explorers visiting abandoned places generate a "sense of authenticity" and allow the cultivation of "solitude in China's overcrowded urban environments." Judith Audin analyses the various ways in which local people and off-site actors (former inhabitants, artists, tourists, heritage activists, or journalists), by expressing memories or other cultural narratives, develop a sense of place in uninhabited Kouquan through their various personal and social interactions with the town in ruins and its abandoned buildings.

To conclude, this special feature on ruination gives special attention to how local communities composed of old and young residents, as well as visitors such as urban explorers, scientists, or journalists, experience ruination processes and appropriate these ordinary spaces through fieldwork photography, dwelling practices, games, memory, and nostalgia in contemporary China. The articles in this special issue bring out how people and communities, including researchers, (re)create communities, lifestyles, and social practices, as well as represent, re-envision, and reimagine the built environment in abandoned buildings and in uninhabited or half-demolished neighbourhoods.

\section{Acknowledgements}

This special feature was driven by a collective reflection in the form of the multidisciplinary workshop entitled "Ruinscapes in Urban China," held on 21 December 2018. The workshop was co-organised with Katiana Le Mentec (CECMC, EHESS) with the support of the French Centre for Research on Contemporary China (CEFC) and the Chinese University of Hong Kong. I would like to thank all the participants to this first workshop. I would also like to thank the CEFC and the editorial team of China Perspectives, as well as Katiana Le Mentec, Tong Lam, and the authors and anonymous reviewers for their precious contributions to this special feature.

I Judith Audin is a former researcher at the CEFC and former Chief Editor of China Perspectives. She is now an associate researcher at the Research Center on Modern and Contemporary China (CECMC), EHESS. CECMC, Campus Condorcet, Bâtiment EHESS, 2 cours des Humanités, 93300 Aubervilliers, France (audin.judith@gmail.com). 


\section{References}

AUDIN, Judith. 2018. "Beneath the Surface of Chinese Cities: Abandoned Places and Contemporary Ruins." Métropolitiques, 28 September 2018. https://www.metropolitiques.eu/Beneath-theSurface-of-Chinese-Cities-Abandoned-Places-and-ContemporaryRuins.html (accessed on 29 November 2019).

AUGÉ, Marc. 2003. Le temps en ruines (Time in Ruins). Paris: Galilée. BRAESTER, Yomi. 2010. Painting the City Red:Chinese Cinema and the Urban Contract. Durham: Duke University Press.

CHU, Julie Y. 2014 "When Infrastructures Attack: The Workings of Disrepair in China." American Ethnologist 41(2): 351-67.

CHU, Kiu-wai. 2012. "Constructing Ruins: New Urban Aesthetics in Chinese Art and Cinema." In Majella MUNRO (ed.), Modern Art Asia: Papers on Modern and Contemporary Asian Art, Issues 1-8. Bourn: Enzo Art and Publishing. 191-212.

DAVIDOV, Veronica. 2016. "Abandoned Environments: Producing New Systems of Value through Urban Exploration." In Ismael VACCARO, Krista HARPER, and Seth MURRAY (eds.), The Anthropology of Postindustrialism: Ethnographies of Disconnection. London: Routledge. 147-65.

DE SOLÀ-MORALES RUBIÓ, Ignasi. 2014. "Terrain Vague" (Wasteland). In Manuela MARIANI, and Patrick BARRON (eds.), Terrain Vague: Interstices at the Edge of the Pale. London: Routledge. 24-30.

GARRETT, Bradley L. 2011. "Assaying History: Creating Temporal Junctions through Urban Exploration." Environment and Planning D 29: 1048-67.

—. 2014a. Explore Everything: Place-hacking the City. New York: Verso Books.

—_. 2014b. "Undertaking Recreational Trespass: Urban Exploration and Infiltration." Transactions of the Institute of British Geographers 39(1): 1-13.

GINZBURG, Carlo. 1980. "Signes, traces, pistes. Racines d'un paradigme de l'indice" (Signs, Traces, Leads. Roots of a Paradigm of the Clue). Le Débat: 3-44.

HO, Cheuk Yuet. 2013. "Exit, or Evict: Re-grounding Rights in Needs in China's Urban Housing Demolition." Asian Anthropology 12(2): 141 55 .

HUANG, Youqin, and Chengdong YI. 2015. "Invisible Migrant Enclaves in Chinese Cities: Underground Living in Beijing, China." Urban Studies 52(15): 2948-73.

JORGENSEN, Anna. 2012. "Introduction." In Anna JORGENSEN, and Richard KEENAN (eds.), Urban Wildscapes. London: Routledge. 1-14.

LAM, Tong. 2013a. "Photo Essay: Unreal Estate and China's Collective Unconscious." Cross-Currents: East Asian History and Culture Review, March 2014. https://cross-currents.berkeley.edu/e-journal/issue-10/ unreal-estate/statement (accessed on 23 October 2017).
—. 2013b. Abandoned Futures: A Journey to the Posthuman World. London: Carpet Bombing Culture.

—. 2020a. "Urbanism of Fear: A Tale of Two Chinese Cold War Cities." In Richard BROOK, Martin DODGE, and Jonathan HOGG (eds.), Cold War Cities: Politics, Culture, and Atomic Urbanism. London: Routledge. 115-21.

—. 2020b. "Unreal Estate: Postsocialist China's Dystopic Dreamscapes." In Thomas LAHUSEN, and Schamma SCHAHADAT (eds.), Postsocialist Landscapes: Real and Imaginary Spaces from Stalinstadt to Pyongyang. Bielefeld: Transcript Verlag. 305-20.

—. 2021. "Where There Is No Room For Fiction: Urban Demolition and the Politics of Looking in Postsocialist China." In Kevin COLMAN, and Daniel JAMES (eds.), Capitalism and the Camera. New York: Verso Books. 209-25.

LEE, Haiyan. 2009. "The Ruins of Yuanmingyuan: Or, How to Enjoy a National Wound." Modern China 35(2): 155-90.

LEFEBVRE, Henri. 1991. The Production of Space. Hoboken: WileyBlackwell.

LE MENTEC, Katiana, and Qiaoyun ZHANG. 2017. "Heritagization of Disaster Ruins and Ethnic Culture in China: Recovery Plans after the 2008 Wenchuan Earthquake." China Information 31(3): 349-70.

LI, Jie. 2009. "Home and Nation amid the Rubble: Fei Mu's Spring in a Small Town and jia Zhangke's Still Life." Modern Chinese Literature and Culture 21(2): 86-125.

- 2020. Utopian Ruins: A Memorial Museum of the Mao Era. Durham: Duke University Press.

MAH, Alice. 2012. Industrial Ruination, Community and Place: Landscapes and Legacies of Urban Decline. Toronto: University of Toronto Press.

MASSEY, Annabella. Forthcoming. The Edges of the City: Frontier Imaginaries in Contemporary Chinese Fiction and Art. PhD Dissertation. Oxford: Oxford University.

MCGRATH, Jason. 2014. "Apocalypse, or, the Logic of Late Anthropocene Ruins." CrossCurrents: East Asian History and Culture Review, March 2014. https://cross-currents.berkeley.edu/sites/default/ files/e-journal/photo-essays/mcgrath_0.pdf (accessed on 26 October 2021).

MESSMER, Matthias, and Hsin-mei CHUANG. 2013. China's Vanishing Worlds: Countryside, Traditions, and Cultural Spaces. Cambridge: MIT Press.

NIESZCZRZEWESKA, Małgorzata. 2015. "Derelict Architecture: Aesthetics of an Unaesthetic Space." Argument 5: 387-97.

OFFENSTADT, Nicolas. 2018. Le pays disparu. Sur les traces de la RDA (The Vanished Country. On the Tracks of the GDR). Paris: Stock. 
ORTELLS-NICOLAU, Xavier. 2015. Urban Demolition and the Aesthetics of Recent Ruins in Experimental Photography from China. PhD Dissertation. Barcelona: Autonomous University of Barcelona.

PADOVANI, Florence. 2005. "Displacement and Resettlement in the Three Gorges Dam." Provincial China 8(2): 164-83.

REN, Xuefei. 2014. "The Political Economy of Urban Ruins: Redeveloping Shanghai." International Journal of Urban and Regional Research 38(3): 1081-91.

SCHULZ, Corey K. N. 2016. "Ruin in the Films of Jia Zhangke." Visual Communication 15(4): 439-60.

SHAO, Qin. 2013. Shanghai Gone: Domicide and Defiance in a Chinese Megacity. Lanham: Rowman \& Littlefield.

SHEPARD, Wade. 2015. Ghost Cities of China: The Story of Cities without People in the World's Most Populated Country. London: Zed Books.

SORACE, Christian. 2017. Shaken Authority: China's Communist Party and the 2008 Sichuan Earthquake. Ithaca: Cornell University Press.

SORACE, Christian, and William HURST. 2015. "China's Phantom Urbanization and the Pathology of Ghost Cities." Journal of Contemporary Asia 46(2): 304-22.

ULFSTJERNE, Michael A. 2017. "The Tower and the Tower: Excess and Vacancy in China's Ghost Cities." In Susanne BREGNBAEK, and Mikkel BUNKENBORG (eds.), Emptiness and Fullness: Ethnographies of Lack and Desire in Contemporary China. New York: Berghahn Books.
VALE, Lawrence J., and Thomas J. CAMPANELLA. 2005. The Resilient City: How Modern Cities Recover from Disaster. Oxford: Oxford University Press.

VALJAKKA, Minna, and Meiqin WANG (eds.). 2018. Urbanized Interface: Visual Arts, Representations and Interventions in Contemporary China. Amsterdam: Amsterdam University Press.

WOODWORTH, Max D., and Jeremy L. WALLACE. 2017. "Seeing Chosts: Parsing China's 'Chost City' Controversy." Urban Geography 38(8): 1270-81.

WU, Fulong, Fangzhu ZHANG, and Chris WEBSTER. 2013. "Informality and the Development and Demolition of Urban Villages in the Chinese Peri-urban Area." Urban Studies 10(50): 1919-34.

WU, Hung. 2012. A Story of Ruins: Presence and Absence in Chinese Art and Visual Culture. London: Reaktion Books.

WU, Kaming, and Jieying ZHANG. 2019. "Living with Waste: Becoming 'Free' As Waste Pickers in Chinese Cities." China Perspectives 117: 6774.

XU, Bin. 2017. The Politics of Compassion: The Sichuan Earthquake and Civic Engagement in China. Stanford: Stanford University Press.

— 2018. "Commemorating a Difficult Disaster: Naturalizing and Denaturalizing the 2008 Sichuan Earthquake in China." Memory Studies 11(4): 483-97. 